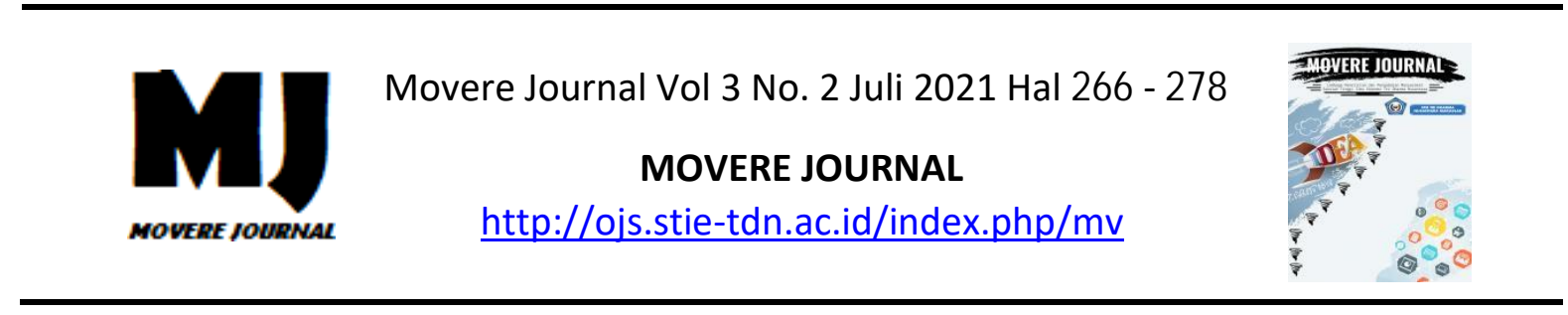

\title{
Pengaruh Net Profit Margin Terhadap Harga Saham Pada PT. Tower Bersama Infrastructure, Tbk
}

\author{
Irmawati $^{1}$, Muhibah ${ }^{2}$ \\ Irmawatiimma0@gmail.com ${ }^{1}$, muhibah.stietdn@gmail.com $^{2}$ \\ Sekolah Tinggi Ilmu Ekonomi Tri Dharma Nusantara ${ }^{1,2}$
}

\begin{abstract}
Abstrak :
Penelitian ini bertujuan untuk mengetahui pengaruh Net Profit Margin (NPM) terhadap harga saham PT. Tower Bersama Infrastructure, Tbk. Jenis data yang digunakan dalam penelitian ini adalah data kuantitatif dan kualitatif dengan sumber data yaitu data sekunder. Metode analisis yang digunakan adalah analisis regresi linear sederhana analisis koefisien kolerasi dan analisis determinasi. Hasil penelitian menunjukkan pengaruh positif antara variabel $\mathrm{Net}$ Profit Margin dan harga saham, yang ditunjukkan dengan $\mathrm{Y}=312,3833+114,9979 \mathrm{x}$. Hubungan antara variabel Net Profit Margin kuat yang ditunjukkan dengan nilai $r=0,8734$. Besarnya pengaruh hubungan antara variabel independen terhadap variabel dependen dengan nilai $\mathrm{r}^{2}=76,28 \%$. Selanjutnya hasil uji hipotesis melalui uji-t diperoleh nilai $\mathrm{t}$ hitung $=$ 3,5868 $>\mathrm{t}$ tabel $=2,131$, sehingga variabel Net Profit Margin berpengaruh signifikan terhadap variabel harga saham. Dengan demikian hipotesis yang diajukan dalam penelitian ini diterima.
\end{abstract}

\begin{abstract}
Abstrak :
This study aims to determine the effect of Net Profit Margin (NPM) on the stock price of PT. Tower Bersama Infrastructure, Tbk. The data type used in this research is quantitative and qualitative data with secondary data as the data source. The analytical method used is simple linear regression analysis, correlation coefficient analysis, and determination analysis. The results showed a positive influence between Net Profit Margin and stock prices, which was indicated by $Y=312.3833+114.9979 x$. The relationship between the Net Profit Margin variables is strong, indicated by the value of $r=0.8734$. The magnitude of the relationship between the independent variables on the dependent variable with a value of $r^{\wedge} 2=76.28 \%$. Furthermore, the results of hypothesis testing through $t$-test obtained the value of $t$ count $=$ 3.5868 t table $=2.131$ so that the Net Profit Margin variable has a significant effect on the stock price variable. Thus the hypothesis proposed in this study is accepted.
\end{abstract}

\section{A. PENDAHULUAN}

Berada di zaman modern saat ini sangat mendorong perkembangan teknologi serta informasi berjalan begitu cepat, dimana persaingan dalam dunia usaha dan bisnis menjadi sangat ketat. Hanya dengan inovasi-inovasi baru yang dapat mempertahankan popularitas dalam

Corresponding Author: Irmawati 
bersaing dunia usaha. Perusahaan harusnya melakukan pengelolaan usaha yang lebih baik demi menghadapi persaingan antar perusahaan dan juga untuk mencari dana alternatif paling cepat yaitu pasar modal dan pasar uang dimana kedua pasar tersebut merupakan sumber utama permodalan eksternal bagi perusahaan dan pemerintah.

Tingkat kebutuhan ekonomi yang semakin besar dan meluas serta ketatnya persaingan dalam dunia bisnis antar sesama perusahaan membuat keuangan dalam perusahan harus mendapatkan perhatian yang lebih. Dalam bidang keuangan merupakan media yang sangat penting dan dibutuhkan dalam proses pengambilan keputusan. Media tersebut adalah berupa laporan keuangan yang diterbitkan secara periode tahunan, semester, triwulan, bulanan, mingguan, atau bahkan harian. Laporan keuangan tersebut sudah menjadi kebutuhan bagi pengusaha, investor, bank, manajemen, pemerintah maupun para pelaku pasar modal.

Pasar modal Indonesia dalam beberapa tahun terakhir telah menjadi perhatian banyak pihak, khususnya masyarakat pebisnis. Ini semua dikarenakan oleh kegiatan pasar modal yang semakin maju serta meningkatnya kebutuhan masyarakat bisnis dalam mencari alternatif sumber pendanaan usaha selain memperoleh dana dari bank. Suatu perusahaan bisa menerbitkan sahamnya serta menjual di pasar modal demi memperoleh dana yang dibutuhkan tanpa perlu membayar beban bunga tetap sebagaimana meminjam dana kebank. Disamping itu meningkatnya kesadaran masyarakat dalam melakukan investasi atau menjadi investor sangat mempengaruhi kemajuan sebuah pasar modal.
Investor sangat berharap ketika melakukan investasi dapat memperoleh sebuah retrun. Dimana perusahaan membutuhkan penilaian investor terhadap saham yang dimiliki perusahaan karena dapat dijadikan sebagai salah satu pengukur kinerja sebuah perusahaan tersebut, sehingga perusahaan berusaha menjaga dan memperbaiki kinerja yang mempengaruhi harga saham supaya saham yang diinvestasikan itu mengalami peningkatan. Kinerja perusahaan yang mendapatkan perhatian lebih dari investor adalah laba dan arus kas, pengukuran kinerja perusahaan diperlukan dalam menentukan keberhasilan perusahaan untuk memberikan tingkat pengembalian sebagai mana yang diharapkan investor adalah sebuah deviden dan capital gain.

Salah satu yang menjadi titik pertimbangan oleh investor yaitu harga saham dimana harga saham menggambarkan mutu dari sebuah perusahaan. Sebelum melakukan investasi, seorang investor perlu mengetahui dan memilih saham-saham mana yang dapat memberikan keuntungan yang paling optimal bagi dana yang diinvestasikan dan investor juga membutuhkan informasi histori maupun ramalan yang akurat, relevan dan tepat waktu. Informasi tersebut dapat berupa seperti informasi berhubungan dengan pola naik turunya harga sebuah surat berharga atau saham di masa lalu atau naik-turunya volume perdagangan. Oleh karena itu dibutuhkan suatu perhitungan lebih dalam atau analisis yang efektif terhadap laporan keuangan tersebut. Sebab pembaca perlu memahami apa arti angka yang ada dan bagaimana menganalisa serta menerangkan data secara logis dan sistematis. Yang mempengaruhi proses terbentuknya harga beli dan harga jual suatu surat berharga adalah informasi yang diperoleh. 
Dengan laporan keuangan perusahaan tersebut, investor dapat memperoleh data atau informasi mengenai Net Profit Margin, jadi dengan menganalisa laporan keuangan mungkin sangat penting bagi manajemen tetapi kurang penting bagi investor.

Net Profit Margin adalah sebuah hubungan antara laba bersih sesudah pajak dengan penjualan memperlihatkan kesanggupan manajemen dalam menjalakan perusahaan sampai pada tahap cukup berhasil dalam mengembalikan atau mengekan harga pokok barang dagangan/jasa, beban operasi, penyusutan dan bunga pinjaman serta pajak (Kasmir 2012:197). Rasio mengambarkan presentasi laba dan penjualan. Dengan demikian peningkatan Net Profit Margin memberikan sinyal positif bagi investor dalam memberikan modalnya kepada perusahaan yang memiliki Net Profit Margin yang tinggi dengan harapan untuk memperoleh deviden yang tinggi.

Berdasarkan hal tersebut, maka penulis mengambil judul Pengaruh Net Profit Margin Terhadap Harga Saham Pada PT. Tower Bersama Infrastructure, Tbk.

Adapun tujuan yang ingin dicapai dalam penelitian ini ialah: "untuk mengetahui pengaruh Net Profit Margin terhadap harga saham pada PT. Tower Bersama Infrastructure, Tbk".

\section{B. TELAAH LITERATUR DAN PENGEMBANGAN HIPOTESIS}

\section{Rasio Profitabilitas (Profitability Ratio)}

Rasio profitabilitas adalah rasio untuk menilai kemampuan perusahaan dalam mencari profit atau laba yang dicapai dalam satu periode tertentu. Menghasilkan laba atau keuntungan yang maksimal merupakan tujuan akhir yang ingin dicapai dari sebuah perusahaan, rasio keuangan atau rasio profitabilitas juga dikenal sebagai rasio rentabilitas. Profitabilitas adalah salah satu indikator yang diperlukan dalam menilai sebuah perusahaan, dimana profitabilitas digunakan untuk mengukur kemampuan perusahaan dalam memperoleh laba profitabilitas dan juga digunakan untuk mengetahui efektivitas perusahaan dalam mengatur aset-aset yang dimiliki.

Husnan dan Pudjiastuti (2015:76), mengemukakan bahwa rasio profitabilitas adalah untuk menilai seberapa jauh perusahaan memperoleh profit dari penjualan aset-aset yang dimiliki, atau dari ekuitas yang dimiliki sebuah perusahaan. Kemudian, Harmono (2015:109), mengemukakan bahwa untuk menjaga kelangsungan hidup suatu perusahaan haruslah selalu berada dalam keadaan yang menguntungkan (profitable), rendahnya keuntungan yang diperoleh akan membuat perusahaan kesulitan untuk menarik modal selain dari kreditor, pemilik perusahaan dan yang paling utama ialah manajemen perusahaan akan berusaha meningkatkan keuntungan ini, karena didasari betapa sangat penting arti keuntungan bagi perusahaan di masa sekarang dan masa depan.

Analisis profitabilitas bertujuan mengukur kesanggupan perusahaan dalam memperoleh laba, baik yang berhubungan dengan penjualan, asset, maupun modal sendiri. Hasil profitabilitas dapat digunakan untuk mengukur ataupun gambaran tentang pencapaian manajemen dlihat dari keuntungan yang didapatkan dibandingkan dengan hasil penjualan dan investasi perusahaan. Konsep profitabilitas ini dalam teori keuangan sering digunakan sebagai indikator kinerja fundamental perusahaan dalam mewakili 
kinerja manajemen. Sesuai dengan perkembangan ragam penelitian dibidang manajemen keuangan, kebanyakan ukuran profitabilitas memiliki hubungan kausalitas terhadap nilai perusahaan. Sedangkan nilai perusahaan secara konsep dapat dijelaskan oleh nilai yang dibentuk oleh harga saham yang diperjualbelikan pasar modal.

Fahmi (2018:80), mengatakan bahwa rasio profitabilitas adalah rasio yang mengukur tingkat efektifitas manajemen secara menyeluruh yang digambarkan oleh besar kecilnya tingkat keuntungan yang diperoleh atas penjualan maupun investasi. Semakin baik profitabilitas maka semakin baik mengambarkan kemampuan tinggi perolehan keuntungan perusahaan. Kemudian, Kasmir (2019:198), mengatakan bahwa rasio profitabilitas adalah rasio untuk menilai kemampuan perusahaan dalam menghasilkan laba. Dengan rasio dapat diketahui ukuran tingkat efektivitas manajemen suatu perusahaan, bisa dilihat dari laba yang diperoleh atas penjualan serta pendapatan investasi. Penggunaan rasio profitabilitas dapat dilhitung dengan menggunakan perbandingan antara komponen yang terdapat dalam laporan keuangan, yaitu laporan keuangan neraca dan laporan laba rugi. Pengukuran dapat dilakukan untuk beberapa periode operasi tertentu.

\section{Net Profit Margin}

Net Profit Margin atau margin laba bersih adalah salah satu dari beberapa rasio profitabilitas. Pada umumnya Net Profit Margin ini berfungsi untuk mengukur tingkat pengembalian keuntungan bersih terhadap penjualan bersih dan mengukur seberapa efisien manajemen dalam mengelola perusahaannya. Net Profit Margin dihitung dengan membagi laba bersih terhadap penjualan bersih. Laba bersih dihitung sebagai hasil pengurangan antara laba sebelum pajak penghasilan dengan beban pajak penghasilan, yang dimaksud dengan laba sebelum pajak ialah laba operasional ditambah pendapatan dan keuntungan lain-lain, selanjutnya dikurangi dengan beban dan kerugian lainlain. Net Profit Margin ialah rasio keuangan yang dipakai untuk menggambarkan kemampuan perusahaan dalam menghasilkan laba bersih atau keuntungan bersih. Kasmir (2019:202) menyatakan bahwa Net Profit Margin adalah ukuran keuntungan dengan membandingkan antara profit sesudah bunga dan pajak dibandingkan dengan penjualan. Semakin besar Net Profit Margin, menandakan kinerja perusahaan semakin produktif sehingga kepercayaan investor akan meningkatkan dan bersedia menanamkan modalnya pada perusahaan tersebut.

Hayat, $\quad$ dkk $\quad(2018: 113)$ mengemukakan bahwa Net Profit Margin itu menunjukkan seberapa besar laba setelah pajak yang dihasilkan oleh setiap satuan nilai moneter dari penjualan yang dilakukan. Menurut Fahmi (2017:136) margin laba yang tinggi menandakan bahwa perusahaan mendapat hasil yang baik yang melebihi harga pokok penjualan dengan begitu akan disukai oleh pihak yang membutuhkan. Hery (2015:235) mengemukakan bahwa Net Profit Margin adalah rasio yang dipakai untuk menilai besarnya presentasi laba bersih atas penjualan bersih. Rasio ini dapat dihitung dengan membagi laba bersih terhadap penjualan bersih. Laba bersih sendiri dihitung sebagai hasil pengurangan antara laba sebelum pajak penghasilan dengan beban pajak penghasilan.

Semakin tinggi margin laba bersih maka laba bersih yang dihasilkan akan ikut 
meningkat yang diperoleh dari penjualan bersih. Hal ini mungkin disebabkan karena tingginya laba sebelum pajak penghasilan. Sebaliknya, jika margin laba bersih rendah berarti laba bersih yang dihasilkan dari penjualan bersih akan rendah. Hal ini dapat terjadi karena tingginya beban pajak dalam periode tertentu atau rendahnya laba sebelum pajak penghasilan. Menurut Fahmi (2017:136) "margin laba yang tinggi menandakan bahwa perusahaan mendapat hasil yang baik yang melebihi harga pokok penjualan dengan begitu akan disukai oleh pihak yang membutuhkan". Adapun rumus rasio Net Profit Margin yaitu dengan membandingkan antara laba sesudah bunga dan pajak dibandingkan dengan penjualan, Kasmir (2019:202).

\section{Saham}

Saham adalah bukti kepemilikan atas suatu perusahaan dimana dalam setiap lembar menunjukkan hak bagi yang memilikinya. Saham adalah keikutsertaan investor dalam perusahaan sebagai pemodal. Saham memberikan pengembalian dalam bentuk deviden (yang biasanya dibayarkan setahun sekali) dan capital gain. Setiap pemegang saham adalah bagian dari pemilik perusahaan, sehingga investor berhak atas sebagian dari laba perusahaan. Namun hak tersebut terbatas karena pemegang saham memiliki hak atas bagian penghasilan perusahanan hanya setelah seluruh kewajiban perusahaan dipenuhi. Pada dasarnya saham dapat digunakan untuk mencapai tiga tujuan investasi yaitu sebagai gudang nilai, untuk pemupukan modal, dan sebagai sumber penghasilan.

$$
\text { Hayat, dkk (2018:253), }
$$
menyatakan bahwa saham merupakan surat berharga yang menunjukkan kepemilikan atas perusahaan sehingga pemegang saham memiliki hak klaim atas deviden atau distribusi lain yang dilakukan perusahaan kepada pemengang saham lainnya. Kemudian, Fahmi (2017:53), menyatakan bahwa saham merupakan kertas yang didalamnya tercantum nilai nominal, nama perusahaan dan diikuti dengan hak dan kewajiban yang dijelaskan kepada setiap pemegangnya.

Saham merupakan surat berharga yang dijual oleh sebuah perusahaan yang berbentuk perseroan yang biasa disebut emiten, dimana pemilik saham tersebut merupakan pemilik sebagian dari perusahaan itu. Secara sederhana saham diartikan sebagai bukti penyertaan atau bukti kepemilikan seseorang atau badan usaha pada sebuah perusahaan, atau suatu tanda bukti berupa surat berharga sebagai pernyataan ikut memiliki modal saham sebuah perusahaan. Saham berwujud selembar kertas yang menerangkan bahwa pemilik kertas adalah pemilik perusahaan yang menerbitkan surat berharga tersebut. Porsi kepemilikan ditentukan oleh seberapa besar modal yang ditanamkan di dalam perusahaan tersebut. Keputusan pembelian saham merupakan suatu bentuk investasi perusahaan dalam bidang commercial paper, artinya keputusan investment in commercial paper yang memiliki nilai profitable.

\section{Harga Saham}

Harga saham merupakan harga yang ada di bursa saham pada saat tertentu yang ditetapkan oleh pelaku pasar sertas permintaan dan penawaran saham yang bersangkutan di pasar modal. Hayat, dkk (2018:259), mengemukakan bahwa saham adalah tanda penyertaan atau kepemilikan seseorang dalam sebuah perusahaan. Setiap lembar saham mempunyai nilai atau harga. Diamana selembar saham adalah selembar kertas yang menjelaskan bahwa pemilik kertas tersebut ialah pemilik 
saham (seberapa pun porsinya/jumlahnya) dari sebuah perusahaan yang menjual kertas saham tersebut. Harga saham adalah harga yang terbentuk sesuai permintaan dan penawaran dipasar jual beli saham dan biasanya merupakan harga penutupan. Harga saham dapat juga didefinisikan sebagai harga yang dibentuk dari interaksi antara penjual dan pembeli saham dilatarbelakangi oleh harapan mereka terhadap keuntungan perusahaan.

Fluktuasi harga Saham ditentukan oleh kesanggupan perusahaan dalam mendapatkan keuntungan (profit). Apabila keuntungan yang diperoleh sebuah perusahaan cukup tinggi, maka sangat memungkinkan deviden yang akan dibayarkan cukup tinggi, atau berpengaruh positif terhadap harga saham di bursa dan investor tertarik untuk membelinya. Dengan begitu permintaan akan saham tersebut meningkat dan pada akhirnya harga saham juga akan meningkat, dimana selembar saham memiliki nilai harga. Disini investor adalah pihak kedua yang membeli saham dari perusahaan yang menjual saham yang sewaktu-waktu investor akan mendapat deviden dari perusahaan tersebut. Investor yang mengharapkan capital gain akan tertarik membeli saham pada saat harga rendah dan menjualnya pada saat harga tinggi.

Harga saham yang terjadi di pasar modal salalu berfluktuasi dari waktu ke waktu. Fluktuasi harga saham tersebut akan ditetapkan oleh kekuatan penawaran dan permintaan. Jika jumlah penawaran lebih besar dari jumlah permintaan, maka kurs harga saham akan mengalami penurunan. Sebaliknya jika jumlah permintaan lebih besar dari jumlah penawaran terhadap suatu efek maka harga saham akan mengalami kenaikan.

\section{Hubungan Net Profit Margin dan}

\section{Harga Saham}

Hery (2016:231), mengemukakan bahwa Net Profit Margin adalah rasio yang mengukur besarnya persentase laba bersih terhadap penjualan bersih. Apabila kemampuan keuangan perusahaan dalam memperoleh laba bersih terhadap penjualan meningkat maka akan mempengaruhi besarnya pendapatan yang akan di terima oleh pemegang saham. Semakin besar Net Profit Margin, maka daya tarik investor akan semakin meningkat, selanjutnya harga saham akan mengalami peningkatan. Net Profit Margin yang tinggi akan memberikan sinyal akan keberhasilan perusahaan dalam mengemban misi dari pemiliknya.

Hubungan antara Net Profit

Margin dengan harga saham juga di kemukakan oleh Tandelilin (2010:386), yaitu Net Profit Margin yang tinggi dapat mengambarkan kinerja perusahaan yang bagus karena dapat memperoleh laba bersih yang besar atas aktivitas penjualannya sehingga saham perusahaan akan menarik minati investor dan akan menaikkan harga saham perusahaan tersebut. Rasio ini tidak mengambarkan besarnya presentase keuntungan bersih yang diperoleh perusahaan untuk setiap penjualan karena adanya unsur pendapatan dan biaya operasional. Net pofit margin yang tinggi dapat menunjukkan kinerja perusahaan yang baik, karena perusahaan dapat menghasilkan laba bersih yang besar melalui aktivitas penjualannya. Oleh sebab itu, saham perusahaan dengan presentase Net Profit Margin yang tinggi akan menarik minati investor dan selanjutnya akan menaikkan saham atas penjualan tersebut.

Apabila kinerja keuangan dalam sebuah peruasahaan untuk menghasilkan pendapatan bersih atas penjualan semakin meningkat maka hal ini akan berdampak 
pada meningkatnya pendapatan yang akan di terima oleh pemegang saham. Semakin meningkat Net Profit Margin maka daya tarik investor semakin tinggi, kemudian harga saham akan ikut mengalami peningkatan. Net Profit Margin (NPM) yang tinggi memberikan sinyal positif akan keberhasilan perusahaan dalam melaksanakan misi dari pemiliknya. Perusahaan yang mampu menghasilkan laba yang besar akan mempengaruhi investor maupun calon investor dalam melakukan investasi. Seorang investor akan bersedia membeli saham dengan harga yang lebih tinggi apabila Net Profit Margin sebuah perusahaan mengalami peningkatan, dan begitupun sebaliknya para investor tidak akan bersedia menanamkan modalnya jika laba dari sebuah perusahaan tersebut itu rendah.

\section{METODE PENELITIAN}

\section{Variabel Penelitian}

Menurut Sugiyono (2016:58), variabel penelitian pada dasarnya adalah segala sesuatu yang berbentuk apa saja yang ditetapkan oleh peneliti untuk dipelajari sehingga diperoleh informasi tentang hal tersebut, kemudian ditarik kesimpulannya. Variabel merupakan indikator terpenting yang menentukan keberhasilan suatu penelitian karena variabel penelitian adalah objek penelitian atau titik perhatian dalam suatu penelitian. Adapun variabel dalam penelitian ini adalah net profit margin (NPM) dan harga saham pada PT.Tower Bersama Infrastructure, Tbk.

\section{Definisi Operasional dan Pengukurannya}

a. Net Profit Margin (NPM), adalah rasio keuangan yangdipakai untuk menggambarkan kemampuan perusahaan dalam menghasilkan laba bersih atau keuntungan bersih.

Net Profit Margin $=\frac{\text { total hutang }}{\text { modal sendiri }}$

b. Harga saham menunjukkan nilai saham perusahaan yang ditunjukkan dengan closing price setiap periode yang diteliti.

\section{METODE ANALISIS DATA \ \\ 1. Analisis Regresi Linear}

Analisis regresi linear sederhana digunakan untuk mengukur hubungan variabel dependen, dimana pada penelitian ini net profit margin (NPM) sebagai variabel independen dan harga saham sebagai variabel dependen. Formulanya yaitu :

$$
Y=a+b x
$$

Keterangan:

Y: variabel dependen a: bilangan konstanta

b: koefisien variabel $x$ $\mathrm{x}$ : variabel independen

Nilai $a$ dan $b$ dapat dihitung dengan menggunakan rumus dibawah ini:

$$
\begin{gathered}
a=\frac{\left(\sum y\right)\left(\sum x^{2}\right)-\left(\sum x\right)\left(\sum x y\right)}{n\left(\sum x^{2}\right)-\left(\sum x\right)^{2}} \\
b=\frac{n\left(\sum x y\right)-\left(\sum x\right)\left(\sum y\right)}{n\left(\sum x^{2}\right)-\left(\sum x\right)^{2}}
\end{gathered}
$$

\section{Analisis Korelasi}

Korelasi merupakan istilah yang digunakan untuk mengukur kekuatan hubungan antar variabel. Menurut Hasan (2014:228) "Analisis korelasi adalah cara untuk mengetahui ada atau tidak adanya hubungan antar variabel misalnya hubungan dua variabel". Apabila terdapat hubungan antarvariabel maka perubahanperubahan yang terjadi pada salah satu 
variabel akan mengakibatkan terjadinya perubahan pada variabel lainnya.. Koefisien korelasi linear dengan metode least aquare dapat digunakan rumus berikut:

$$
r=\frac{n \sum x y-\left(\sum x\right)\left(\sum y\right)}{\sqrt{\left\{n \Sigma x^{2}-\left(\sum x\right)^{2}\right\}\{n \Sigma y 2-(\Sigma y) 2\}}}
$$

$\mathrm{n}$ = Banyaknya Pasangan data X dan $\mathrm{Y}$

$\Sigma \mathrm{x}=$ Total Jumlah dari Variabel $\mathrm{X}$

$\Sigma \mathrm{y}=$ Total Jumlah dari Variabel Y

$\Sigma \mathrm{X}^{2}=$ Kuadrat dari Total Jumlah Variabel $\mathrm{X}$

$\Sigma \mathrm{y}^{2}=$ Kuadrat dari Total Jumlah Variabel $\mathrm{Y}$

$\Sigma x y=$ Hasil Perkalian dari Total Jumlah Variabel X dan Variabel Y

\section{Uji t}

Uji $\mathrm{t}$ dikenal dengan uji parsial yaitu untuk menguji bagaimana pengaruh masing-masing variabel bebasnya secara sendiri-sendiri terhadap variabel terikatnya. Pengujian hipotesis dimaksudkan sebagai cara untuk menentukan apakah suatu hipotesis tersebut sebaiknya diterima atau ditolak. Pada penelitian ini nilai $\mathrm{t}$ hitung akan dibandingkan dengan $t$ tabel pada tingkat signifikan $(\alpha)=5 \%$. Kriteria pengambilan keputusan pada uji t ini adalah :

Tabel 1. Hasil perhitungan Net Profit Margin PT. Tower Bersama Infrastructure Tbk. (dinyatakan dalam jutaan rupiah kecuali dalam bentuk lain)

\begin{tabular}{|c|c|c|c|}
\hline Tahun & Laba Bersih & Penjualan Bersih & Net Profit Margin $(\%)$ \\
\hline 2015 & 1.445 .027 & 3.421 .177 & 42,23 \\
\hline 2016 & 1.301 .393 & 3.711 .174 & 35,06 \\
\hline 2017 & 2.339 .029 & 4.023 .085 & 58,14 \\
\hline 2018 & 702.632 & 4.318 .137 & 16,27 \\
\hline 2019 & 866.121 & 4.698 .742 & 18,43 \\
\hline 2020 & 1.066 .576 & 5.327 .689 & 20,01 \\
\hline
\end{tabular}

Sumber: Data diolah, 2021

Berdasarkan tabel 3, hasil dari perhitungan Net Profit Margin PT. Tower Bersama
H0 diterima jika : $\mathrm{t}$ hitung $<\mathrm{t}$ tabel atau nilai thitung $>0,05$

$\mathrm{H} 1$ diterima jika : $\mathrm{t}$ hitung $>\mathrm{t}$ tabel atau nilai t hitung $<0,05$

a. Untuk menentukan $t$ hitung dengan menggunakan rumus :

$$
t=\frac{r \sqrt{n-2}}{\sqrt{1-r^{2}}}
$$

Keterangan :

$\mathrm{t}: \mathrm{t}$ hitung

r: koefisien korelasi

$\mathrm{n}$ : jumlah data

b. Untuk menentukan t tabel

Tabel distribusi t dicari pada $\alpha=5 \%$ dengan menggunakan uji satu arah dengan derajat kebebasan (df) n-k-1, dimana $n$ adalah jumlah data dan $\mathrm{k}$ adalah jumlah variabel independen.

\section{E. HASIL DAN PEMBAHASAN}

\section{Analisis Net Profit Margin}

Data keuangan yang di gunakan untuk mengukur Net Profit Margin (NPM) adakah dengan membandingkan antara laba setelah bunga dan pajak dibandingkan dengan penjualan dan dikalikan $100 \%$. Rasio ini menunjukkan pendapatan bersih perusahaan atas penjualan. (Kasmir, 2019:202) 
sampai tahun 2020 mengalami fluktuasi dari hasil laba bersih yang diperoleh. Pada tahun 2015 perusahaan memperoleh Net Profit Margin sebesar 42,23\%, pada tahun 2016 perusahaan memperoleh Net Profit Margin sebesar 35,06\%, pada tahun 2017 perusahaan memperoleh Net Profit Margin sebesar 58,14\%, pada tahun 2018 Net Profit Margin mengalami penurunan sebesar 16,27\%, pada tahun 2019 Net Profit Margin mengalami penurunan sebesar $18,43 \%$ dan pada tahun $2020 \mathrm{Net}$ Profit Margin mengalami peningkatan sebesar 20,01\%. Penyebab terjadinya fluktuasi pada perusahaan PT. Tower Bersama Infrastructure Tbk. Karena laba

Tabel 2. Harga Saham PT. Tower Bersama Infrastructure Tbk, tahun 2015 sampai pada tahun 2019

\begin{tabular}{|c|c|c|}
\hline Tahun & Harga Saham & Perubahan \\
\hline 2015 & 5.875 & 0 \\
\hline 2016 & 4.980 & $(0,125)$ \\
\hline 2017 & 6.425 & 0,290 \\
\hline 2018 & 3.600 & $(0,439)$ \\
\hline 2019 & 1.230 & $(0,667)$ \\
\hline 2020 & 1.630 & 0,325 \\
\hline
\end{tabular}

Sumber: Data diolah, 2021

Dari tabel di atas, harga saham yang diambil yaitu harga saham penutup (closing price) dimana pada tahun 2015 harga saham penutupnya sebesar 5.875, pada tahun 2016 harga saham penutupnya sebesar 4.980, pada tahun 2017 harga saham penutupnya sebesar 6.425 , pada tahun 2018 harga saham penutupnya sebesar 3.600, pada tahun 2019 harga saham penutupnya adalah 1.230 dan pada tahun 2020 harga saham penutupannya sebesar 1.630. Dari data tabel di atas dapat disimpulkan bahwa harga saham PT. Tower Bersama Infrastructure Tbk, yang tertinggi berada pada tahun 2017 yaitu sebesar 6.425, dan untuk harga saham terendah berada pada tahun 2019, artinya bersih yang diperoleh mengalami mengalami peningkatan.

\section{Harga Saham PT. Tower Bersama Infrastructure Tbk,}

Variabel independen dalam penelitian ini yaitu harga saham (Y), harga saham merupakan harga yang ada pada bursa efek yang ditentukan oleh permintaan dan penawaran saham. Menurut Sartono (2008:70), Harga saham adalah harga yang terbentuk melalui mekanisme permintaan dan penawaran di pasar modal. nilai harga saham dari tahun 2015 sampai pada tahun 2020 mengalami fluktuasi.

\section{Analisis Regresi Linear Sederhana}

Untuk mengetahui ada tidaknya pengaruh Net Profit Margin dengan harga saham maka dalam penelitian ini digunakan analisis regresi linear sederhana. Analisis ini bertujuan untuk mengetahui apa hubungan antara $\mathrm{Net}$ Profit Margin dan harga saham apakah berpengaruh posistif atau negatif.

Regresi linear sederhana terdiri atas dua variabel, yaitu variabel terikat yang diberi simbol $\mathrm{Y}$ dan variabel bebas yang diberi simbol X. Dalam memprediksikan nilai variabel $\mathrm{Y}$ maka digunakan 
perhitungan persamaan dengan rumus sebagai berikut:

$$
\mathrm{Y}=\mathrm{a}+\mathrm{bX}
$$

Keterangan:

Y: Variabel terikat harga saham

X: Variabel bebas Net Profit Margin

a: Konstanta

b: Koefisien variabel X

Untuk melengkapi persamaan diatas maka perluh dicari nilai $a$ dan $b$ yang dapat dihitung menggunakan rumus:

Tabel 3. Perhitungan analisis regresi liniear sederhana

\begin{tabular}{|c|c|c|c|c|c|}
\hline Tahun & $\mathrm{X}$ & $\mathrm{Y}$ & $\mathrm{X} . \mathrm{Y}$ & $\mathrm{X}^{2}$ & $\mathrm{Y}^{2}$ \\
\hline 2015 & 42,23 & 5.875 & $248.101,25$ & $1.783,3729$ & 34.515 .625 \\
\hline 2016 & 35,06 & 4.980 & $174.598,8$ & $1.229,2036$ & 24.800 .400 \\
\hline 2017 & 58,14 & 6.425 & $373.549,5$ & $3.380,2596$ & 41.280 .625 \\
\hline 2018 & 16,27 & 3.600 & 58.572 & 264,7129 & 12.960 .000 \\
\hline 2019 & 18,43 & 1.230 & $22.668,9$ & 339,6649 & 1.512 .900 \\
\hline 2020 & 20,01 & 1.630 & $32.616,3$ & 400,4001 & 2.656 .900 \\
\hline Jumlah $\left(\sum\right)$ & 190,14 & 23.740 & $910.106,75$ & $7.397,614$ & 117.726 .450 \\
\hline
\end{tabular}

Sumber : Data diolah 2021

Untuk memperoleh nilai a dan $b$, maka hasil dari perhitungan diatas disubtitusikan kedalam persamaan $a$ dan $b$ sebagai berikut:

Untuk nilai $\mathrm{b}=\frac{\mathrm{n} \sum \mathrm{xy}-\left(\sum \mathrm{x}\right)\left(\sum \mathrm{y}\right)}{\mathrm{n} \sum \mathrm{x}^{2}-\left(\sum \mathrm{x}\right)^{2}}$

$\mathrm{b}=\frac{6(910.106,75)-(190,14)(23.740)}{6(7.397,614)-(190,14)^{2}}$

$=\frac{5.460 .640,5-4.513 .923,6}{44.385,684-36.153,2196}$

$=\frac{946.716,9}{8.232,4644}$

$=114,9979$

Untuk nilai $\mathrm{a}=\frac{\sum \mathrm{y}}{\mathrm{n}}-\frac{\sum \mathrm{x}}{\mathrm{n}}$

$\mathrm{a}=\frac{23.740}{6}-\frac{(114,9979)(190,14)}{6}$

$=3.956,66666667-3.644,283451$

$=312,3833$

Jadi hasil perhitungan persamaan nilai regresi linear sederhana diatas menjelaskan bahwa adanya pengaruh positif terhadap nilai saham PT.

$$
\begin{gathered}
\mathrm{a}=\frac{\sum y}{n}-\frac{\sum \mathrm{x}}{n} \\
\mathrm{~b}=\frac{n \sum x y-\left(\sum x\right)\left(\sum y\right)}{n \sum x^{2}-\left(\sum x\right)^{2}}
\end{gathered}
$$

Dibawah ini adalah perhitungan dengan menggunakan regresi linear sederhana untuk pengaruh Net Profit Margin terhadap harga saham pada PT. Tower Bersama Infrastructure Tbk, tahun 2015 sampai dengan tahun 2020 yaitu sebagai berikut.
Tower Bersama Infrastructure Tbk, adapun nilai yang diperoleh adalah sebagai berikut:

$\mathrm{Y}=312,3833+114,9979 \mathrm{x}$

Berdasarkan persamaan diatas dapat diinterpretasikan sebagai berikut:

$\mathrm{a}=312,3833$, berarti tanpa variabel $\mathrm{x}$ Net Profit Margin (NPM), nilai harga saham tetap sebesar Rp 312,3833.

$\mathrm{b}=114,9979$, berarti setiap kenaikan 1 satuan Net Profit Margin (NPM), maka akan meningkatkan harga saham sebesar Rp 114,9979.

\section{Analisis Koefisien Korelasi}

Analisi kolerasi juga disebut koefisien kolerasi adalah nilai yang menunjukkan kekuatan dan arah hubungan linear antara dua peubah acak. Analisis kolerasi digunakan untuk mencari 
hubungan antara dua atau lebih variabel yang diteliti. Perhitungan ini mengisyaratkan bahwa populasi asal

$$
\begin{gathered}
\mathrm{r}=\frac{\mathrm{n}\left(\sum \mathrm{xy}\right)-\left(\sum \mathrm{x}\right)\left(\sum \mathrm{y}\right)}{\sqrt{\left\{\mathrm{n}\left(\sum \mathrm{x}^{2}\right)-\left(\sum \mathrm{x}\right)^{2}\right\}\left\{\mathrm{n}\left(\sum \mathrm{y}^{2}\right)-\left(\sum \mathrm{y}\right)^{2}\right\}}} \\
\mathrm{r}=\frac{6(910.106,75)-(190,14)(24.740)}{\sqrt{\left\{6(7.397,614)-(190,14)^{2}\right\}\left\{6(117.726 .450)-(23.740)^{2}\right\}}} \\
\mathrm{r}=\frac{5.460 .640,5-4.013 .923,6}{\sqrt{\{8.232,4644\}\{142.721 .100\}}} \\
\mathrm{r}=\frac{946.716,9}{\sqrt{1.174 .946 .374 .879}} \\
\mathrm{r}=\frac{946.716,9}{1.083 .949,43373} \\
\mathrm{r}=0,8734
\end{gathered}
$$

Dari hasil perhitungan analisis koefisien korelasi diatas, dapat dilihat bahwa nilai $r=0,8734$. Berdasarkan perhitungan dari koefisien kolerasi dalam waktu lima tahun terakhir dapat dikategorikan kedalam hubungan yang sangat kuat.

\section{Analisis Determinasi}

Menurut Sugiyono (2008:33), metode koefisien determinasi menunjukkan seberapa besar pengaruh (dalam bentuk persen) hubungan antara variabel indevenden terhadap variabel dependen.

$$
\mathrm{r}^{2}=\mathrm{rx} \mathrm{r}
$$

Dimana $r$ adalah koefisien kolerasi

$$
\begin{gathered}
r^{2}=0,8734 \times 0,8734 \\
r^{2}=0,76282756 \\
r^{2}=76,28 \%
\end{gathered}
$$

Dari nilai $r^{2}=0,7616319458$ dapat dijelaskan bahwa kemampuan Net Profit Margin (NPM) dalam mempengaruhi saham sebesar 76,28\% dengan sisa $23,72 \%$ dipengaruhi variabel lain diluar dari $\mathrm{Net}$ Profit Margin.

\section{Uji Hipotesis}

Ghozali (2018:152) mengatakan bahwa uji t digunakan untuk mengetahui masing-masing variabel independen terhadap variabel devenden. Jika thitung $>$ ttabel atau nilai signifikansi uji $\mathrm{t}<0,05$ maka disimpulkan bahwa secara individual variabel independen berpengaruh signifikan terhadap variabel dependen. Tingkat signifikan yang digunakan dalam uji t ini adalah sebesar 5\% dengan level of confidance $95 \% \quad(0,05)$ nilai yang dikemukakan menurut Sugiyono (2008:230) dapat dicari dengan rumus sebagai berikut:

Dimana :

$$
\text { thitung }=r \sqrt{\frac{n-2}{1-r^{2}}}
$$

$\mathrm{t}$ : Uji signifikan

$\mathrm{r}$ : Koefisisen korelasi

$\mathrm{n}$ : Jumlah periode (tahun)

Nilai tabel memiliki derajat bebas $=\mathrm{n}-2=$ $6-2=4$, Maka ttabel $=2,131$

Jadi hasil perhitungan untuk uji $\mathrm{t}$ yaitu sebagai berikut:

$$
\begin{array}{r}
t=r \sqrt{\frac{n-2}{1-r^{2}}} \\
t=0,8734 \sqrt{\frac{6-2}{1-0,76282756}} \\
=0,8734 \sqrt{\frac{4}{0,238717244}}
\end{array}
$$




$$
\begin{gathered}
=0,8734 \sqrt{16,8653659759} \\
=0,8734(4,10674639781) \\
t=3,5868
\end{gathered}
$$

Dari hasil perhitungan diatas maka yang diperoleh nilai hitung $t$ hitung sebesar 3,5868 karena nilai $\mathrm{t}$ hitung = $3,5868>\mathrm{t}$ tabel $=2,131$ maka dapat diketahui bahwa h0 ditolak dan menerima h1.

\section{F. KESIMPULAN}

Berdasarkan hasil pembahasan dan analisis maka dapat disimpulkan bahwa Net Profit Margin berpengaruh positif dan signifikan terhadap harga saham pada PT. Tower Bersama Infrastructure Tbk.

Dengan melihat nilai persamaan linear $\mathrm{Y}=312,3833+114,9979 \mathrm{x}$ menjelaskan bahwa adanya pengaruh positif terhadap nilai saham dan koefisien korelasi sebesar $\mathrm{r}=0,8734$ dapat dikategorikan kedalam hubungan yang sangat kuat, serta nilai koefisien determinasi sebesar 76,28\% bahwa terdapat pengaruh antara variabel independen dengan variabel dependen dan sisanya sebesar $23,72 \%$ yang dipengaruhi oleh variabel lain diluar variabel Net Profit Margin.

Untuk hasil uji t membuktikan bahwa terdapat pengaruh signifikan terhadap variabel Net Profil Margin dengan harga saham pada PT. Tower Bersama Infrastructure Tbk, dengan membandingkan nilai hitung thitung dan ttabel dimana thitung $=3,5868>$ ttabel $=$ 2,131 dengan tingkat signifikan 5\% $(0,05)$.

\section{DAFTAR PUSTAKA}

Agus, Sartono. 2008. Manajemen Keuangan Teori dan Aplikasi. Edisi Empat. Yogyakarta: BPFF.

Egam, Edsel Yermia ,Gerald, dkk. 2017. Pengaruh Return On Asset (ROA), Return On Equity (ROE), Net Profit Margin (NPM), dan Earning Per Share (EPS) terhadap harga saham perusahaan yang tergabung dalam indeks LQ45 periode 2013-2015. Jurnal Ekonomi dan Bisnis.Vol.5 No.1.

Fahmi, Irham. 2018. Pengantar Manajemen keuangan, Alfabeta, Bandung

- 2017. Analisis Laporan
keuangan, Alfabeta, Bandung

2015. Analisis Kinerja Keuangan, alafabeta, bandung.

Ghozali, imam. 2018. Aplikasi Analisis Multivariat dan Program IBM SPSS 25. Badan Penerbit Universitas Diponegoro: Semarang.

Harahap, Sofyan Syafri. 2013. Analisis Kritis Atas Laporan Keuangan. Jakarta: PT Raja Grafindo Persada.

Harmono. 2015 Manajemen keuangan Berbasis Belanced Scorecard Pendekaan Teori, Khusus dan Riset Bisnis. Cetakan keenam, Bumi Aksara. Jakarta.

2017. Manajemen keuangan Berbasis Belanced Scorecard Pendekaan Teori, Khusus dan Riset Bisnis. Cetakan keenam, Bumi Aksara. Jakarta.

Hayat, Atma, dkk. 2018. Manajemen Keuangan, Madenatera Indomedia Pustaka,Sidoarjo. Harmono. 2017. Manajemen keuangan Berbasis Belanced Scorecard Pendekaan Teori, Khusus dan Riset Bisnis. Cetakan keenam, Bumi Aksara. Jakarta.

Hery. 2015. Analisis Kinerja Manajemen The Best Financial Analysis Menilai Kerja Manajemen Berdasarkan Rasio Keuangan. Jakarta. 2016. Analisis Laporan Keuangan. Jakarta: Grasindo.

Husnan, Suad dan Pudjiastuti, Enny. 2015. Dasar-dasar Manajemen Keuangan. Edisi Ketujuh. Unit Penerbit dan Percetakan (STIM YKPN), Yogyakarta.

Hutapea Alberta W, dkk 2017. Pengaruh Return On Asset (ROA), Net Profit 
Margin (NPM), Debt to Equity dan asset Tornover terhadap harga saham industry otomotif dan komponen yang terdaftar di bursa efek Indonesia. Jurnal EMBA Vol.5 No.2.

Kasmir. 2012. Anlisis Laporan Keuangan, PT. Raja Grafindo Persada, Jakarta.

- 2019. Anlisis Laporan Keuangan, PT. Raja Grafindo Persada, Jakarta. 2017. Analisis Laporan Keuangan, PT. Raja Grafindo Persada, Jakarta.

Mantasia. 2019. Pengaruh Net Profit Margin Terhadap Harga Saham Pada PT. Midi Utama Indonesia, Tbk. Skrippsi Tidak Diterbitkan.

Manoppo Vera Ch.O., dkk, 2017. Pengaruh Current Ratio, DER,ROA dan NPM terhadap harga saham pada perusahaan Food and Beverages yang terdaftar di BEI periode 2013-2015. Jurnal Ekonomi dan Bisnis. Vol.5 No.2.

Musthafa. 2017. Manajemen Keuangan, CV. Andi Offset, Yogyakarta.

Setia, muliyawan.2015. Manajemen keuangan. CV pustaka setia, Bandung.

Sugiyono, 2008. Metode penelitian kuantitatif, kualitatif dan $R \& D$, Alfabeta, Bandung.

\begin{tabular}{lll}
\hline Kuantitatif dan $R \& D$, & Metode & Penelitian \\
Bandung. & &
\end{tabular}

Syamsuddin , Lukman. 2017. Manajemen keuangan perusahaan. Jakarta. Rajawali Pers.

Tandelilin, Eduardus. 2010. Portofolio dan investasi : teori dan aplikasi edisi pertama . Yogyakarta. Kanisius.

2012. analisis investasi dan manajemen portofolio. Edisi ketiga, Yogyakarta: BPFF-Yogyakarta.

Wangarry Andreas R, dkk, 2015. Pengaruh tingkat Returnn On Investement (ROI), Net Profit Margin (NPM),dan Debt To Equity
Ratio (DER) terhadap harga saham perbankan di bursa efek indonesia (BIE). Jurnal Ekonomi dan Bisnis Vol.3 No.4.

Watung Rosdian Widiawati dan Vetjen Ilat, 2016. Pengaruh Return On Asset (ROA), Ne Profit Margin (NPM), dan Earning Per Share (EPS) terhadap harga saham pada perusahaan perbankan di Bursa efek Indonesia periode 2011-2015. Jurnal Ekonomi dan Bisnis Vol.4 No.2. 